\title{
Inter- and intraspecific functional variability of tropical arbuscular mycorrhizal fungi isolates colonizing corn plants
}

\author{
Cândido Barreto de Novais ${ }^{a}$, Wardsson Lustrino Borges ${ }^{\mathrm{b}}$, Ederson da Conceição Jesus ${ }^{\mathrm{c}}$, \\ Orivaldo José Saggin Júnior ${ }^{\mathrm{c}}$, José Oswaldo Siqueira ${ }^{\mathrm{d}, *}$
}

a Universidade Federal de Lavras, DCS-Laboratório de Microbiologia do Solo, Caixa Postal 3037, CEP 37200-000, Lavras, MG, Brazil

b Embrapa Amapá, Rodovia Juscelino Kubitschek, km 5, N²600, CEP 68903-419, Macapá, AP, Brazil

${ }^{\mathrm{c}}$ Embrapa Agrobiologia, Rodovia BR 465, km 7, Seropédica, RJ, CEP: 23891-000, Brazil

d Vale Technological Institute-Mining, Rua Antonio de Albuquerque, $2719^{\circ}$ andar, 30112010 Belo Horizonte, MG, Brazil

\section{A R T I C L E I N F O}

\section{Article history:}

Received 2 August 2013

Received in revised form

10 December 2013

Accepted 18 December 2013

\section{Keywords:}

RFLP

Geographical isolates

Glomus

Gigaspora

Acaulospora

\begin{abstract}
A B S T R A C T
For a single plant species under the same environmental conditions, the interaction with arbuscular mycorrhizal fungi (AMF) and their contribution to plant growth varies among AMF isolates, with both inter and intraspecific variability. The present study evaluated the functional variability of 41 isolates of 20 species and eight genera of AMF for root colonization, growth promotion, and $P$ uptake of corn and observed the relationship of this functional variability with the isolates genetic variability revealed by PCR-RFLP analysis. All the isolates abundantly colonized the corn roots, but only 23 promoted higher shoot dry mass and $P$ leaf content. The cluster analysis based on functional variability data separated the isolates Acaulospora morrowiae (Am2), Acaulospora sp. (Aca), A. colombiana (Ac3, Ac4, and Ac5), Gigaspora albida (Gia1), Gi. margarita (Gim4 and Gim5), Gi. rosea (Gir), Rhizophagus clarus (Rc2, Rc3, Rc4, Rc5, and Rc6), Claroideoglomus etunicatum (Ce4), R. manihotis (Rm), Scutellospora calospora (Sc), S. heterogama (Sh2, Sh3, Sh4, and Sh5) and S. pellucida (Sp3) from the others at the distance of $80 \%$ functional similarity. These were considered efficient in promoting functional symbiosis in corn while the other isolates were considered inefficient. The cluster analysis obtained by the PCR-RFLP technique was partly coherent with the species classification based on spore morphology. The isolates of $R$. clarus fell into one cluster and the isolates of the Gigaspora and Scutellospora genera (Gigasporaceae family) were clustered in a second cluster, without the ability to separate the species of these genera.
\end{abstract}

(C) 2014 Elsevier B.V. All rights reserved.

\section{Introduction}

The arbuscular mycorrhizal fungi (AMF) form symbiotic relationships with the majority of land plant species and are distributed throughout the tropics. This association is characterized by the penetration of the fungal mycelium between and within the cells of the radicular cortex, without causing visible morphological change to the naked eye, but that modifies the plant's physiology, enhancing its capacity to absorb nutrients from the soil, especially those with low soil mobility such as phosphorus. For the same plant species, the effects and contribution of AMF vary according to the fungal isolates, reflected in differences in the symbiotic efficiency of the fungus (van der Heijden and Kuyper, 2001). This variation is well

\footnotetext{
* Corresponding author. Tel.: +55 3131944083.

E-mail addresses: candidobnn@yahoo.com.br (C.B. de Novais), wardsson.borges@embrapa.br, wardsson@gmail.com (W.L. Borges), ederson.jesus@embrapa.br (E.d.C. Jesus),saggin@cnpab.embrapa.br (O.J.S. Júnior), jose.oswaldo.siqueira@vale.com (J.O.Siqueira).
}

documented, but the mechanisms that regulate these interactions and effects are poorly understood. This leaves doubt about the role of AMF in crop yields and recuperation of degraded ecosystems hampering the definition of strategies for the application of these fungi.

At present 230 AMF species are known (Schüßler and Walker, 2010), a number considered low compared to the number of plant species with which these fungi can associate. This situation induces the view that AMF form a homogenous group of symbionts in which all the species perform identical biological functions in the ecosystem (Husband et al., 2002).

The use of molecular techniques based on PCR-RFLP (polymerase chain reaction - restriction fragment length polymorphism) has allowed verification that the AMF community in the rhizosphere varies among plant species (Babu and Reddy, 2011; Martínez-García and Pugnaire, 2011) and among soils with different concentrations of nutrients (Martinez-García et al., 2011). It has been found that the community variability is greater in the rhizosphere than in the roots (Martinez-García et al., 2011; Miras-Avalos et al., 2011), suggesting some degree of preference or specificity. 
According to Wagg et al. (2011), due to the seemingly limitless possibilities for complementarity or selection effect, it is difficult, if not impossible, to determine all the functional and resource-based niches that each AMF species within a more AMF-rich community can occupy to influence, and thus direct, the richness-plant productivity relationship.

Great functional variability of AMF has been detected, both regarding species and isolates of the same species defined based on spore morphology (Avio et al., 2006; Munkvold et al., 2004; Smith et al., 2004). However, these studies evaluated a small number of isolates of a single genus (Glomus). The present study is the first to assess a large number of isolates, encompassing various species and genera from tropical ecosystems, regarding their functional variability in relation to a single plant species.

In general, the symbiotic efficiency of an AMF isolates is attributed to two main factors: the ability to abundantly colonize the roots and the ability to promote beneficial responses for the host plant's nutrition and growth. The difference in symbiotic performance observed among different AMF isolates is considered as a measure of the functional variability of mycosymbionts (PouyuRojas et al., 2006). Corn shows high growth rate, high uptake of nutrients, and high level of mycotrophy making it an ideal host for studies to assess the functional variability of AMF. Therefore, the aim of this work was to evaluate the functional variability, both among the species of different genera and different isolates of the same species of AMF, regarding root colonization, growth effects, and phosphorous uptake of corn, Zea mays L. (Poaceae).

\section{Material and methods}

\subsection{Fungal material}

A total of 42 AMF isolates belonging to 20 species and 8 genera were used in this study (Table 1). Initially, to reduce the

Table 1

List of the AMF isolates studied in this work.

\begin{tabular}{|c|c|c|c|c|c|c|c|}
\hline Family $^{\mathrm{a}}$ & Species $^{\mathrm{a}}$ & Code of origin ${ }^{\mathrm{b}}$ & Code $^{c}$ & Plant of origin & Location of origin & Biome of origin & $\begin{array}{l}\text { Institution } \\
\text { of origin }^{\mathrm{d}}\end{array}$ \\
\hline Acaulosporaceae & Acaulospora colombiana & A87 (CNPAB 043) & Ac1 & Gleichenia sp. & Itumirim, MG & Cerrado & CNPAB \\
\hline Acaulosporaceae & Acaulospora colombiana & A15 (CNPAB 015) & Ac2 & Zea mays & Barra do Piraí, RJ & Atlantic forest & CNPAB \\
\hline Acaulosporaceae & Acaulospora colombiana & ALCOA-CCB2 & Ac3 & - & Minas Gerais & Cerrado & UFLA \\
\hline Acaulosporaceae & Acaulospora colombiana & 06-UFLA & Ac4 & - & - & - & UFLA \\
\hline Acaulosporaceae & Acaulospora colombiana & AMZ570A & Ac5 & - & Benjamin Constant, AM & Amazon forest & FURB \\
\hline Acaulosporaceae & Acaulospora morrowiae & 401-UFLA & Am1 & Native grasses & Três Marias, MG & Cerrado & UFLA \\
\hline Acaulosporaceae & Acaulospora scrobiculata & A38 (IES-33) & As1 & $-g$ & IES $^{\mathrm{e}}$ (Cuba) & - & CNPAB \\
\hline Acaulosporaceae & Acaulospora scrobiculata & ALCOA29 & As2 & - & Poços de Caldas, MG & Atlantic forest & UFLA \\
\hline Acaulosporaceae & Acaulospora spinosa & 95-UFLA & Asp & - & - & Cerrado & UFLA \\
\hline Acaulosporaceae & Acaulospora sp. & A88 (CNPAB 044) & Aca & Gleichenia sp. & Itumirim, MG & Cerrado & CNPAB \\
\hline Claroideoglomeraceae & Claroideoglomus etunicatum & 365-UFLA & Ce1 & Coffea arabica & Patrocínio, MG & Cerrado & UFLA \\
\hline Claroideoglomeraceae & Claroideoglomus etunicatum & URM-FMA 03 & $\mathrm{Ce} 2$ & - & - & - & UFPE \\
\hline Claroideoglomeraceae & Claroideoglomus etunicatum & - & Ce3 & - & Santa Catarina & - & ESALq \\
\hline Claroideoglomeraceae & Claroideoglomus etunicatum & SCT101A & Ce4 & Malus domestica & Santa Catarina & Pinhais forest & FURB \\
\hline Glomeraceae & Glomus formosanum & A20 (CNPAB 020) & Gf & Imperata brasiliensis & Barra do Piraí, RJ & Atlantic forest & CNPAB \\
\hline Glomeraceae & Rhizophagus clarus & A5 (CNPAB 005) & Rc1 & - & INVAM $^{\mathrm{f}}$ & - & CNPAB \\
\hline Glomeraceae & Rhizophagus clarus & URM-FMA 08 & $\mathrm{Rc} 2$ & - & - & - & UFPE \\
\hline Glomeraceae & Rhizophagus clarus & CMM-306 & Rc3 & Native grasses & Três Pontas, MG & Cerrado & UFLA \\
\hline Glomeraceae & Rhizophagus clarus & - & Rc4 & - & Florianópolis, SC & - & ESALq \\
\hline Glomeraceae & Rhizophagus clarus & 351-UFLA & Rc5 & - & Flórida, EUA & - & UFLA \\
\hline Glomeraceae & Rhizophagus clarus & A90 (CNPAB 046) & Rc6 & Canavalia rosea & Recife, PE & Planície costeira & CNPAB \\
\hline Glomeraceae & Rhizophagus manihotis & A83 (CNPAB 041) & $\mathrm{Rm}$ & Manihot esculenta & Seropédica, RJ & Atlantic forest & CNPAB \\
\hline Gigasporaceae & Gigaspora albida & URM-FMA 01 & Gia1 & - & - & - & UFPE \\
\hline Gigasporaceae & Gigaspora albida & 03-UFLA MG & Gia2 & Native grasses & Três Marias, MG & Cerrado & UFLA \\
\hline Gigasporaceae & Gigaspora candida & A36 (IES-29) & Gic1 & - & IES $^{\mathrm{e}}$ (Cuba) & - & CNPAB \\
\hline Gigasporaceae & Gigaspora candida & $\mathrm{BEG} 17^{\mathrm{h}}$ & Gic2 & - & Taiwan & $\begin{array}{l}\text { Tropical } \\
\text { agricultural }\end{array}$ & BEG \\
\hline Gigasporaceae & Gigaspora margarita & A49 (Inóculo 138) & Gim1 & Coffea arabica & Patrocínio, MG & Cerrado & CNPAB \\
\hline Gigasporaceae & Gigaspora margarita & A1 (CNPAB 001) & $\operatorname{Gim} 2$ & - & Flórida, EUA & - & CNPAB \\
\hline Gigasporaceae & Gigaspora margarita & A41 (IES-42) & Gim3 & - & IES $^{\mathrm{e}}$ (Cuba) & - & CNPAB \\
\hline Gigasporaceae & Gigaspora margarita & 279-UFLA & Gim4 & - & - & - & UFLA \\
\hline Gigasporaceae & Gigaspora margarita & R1 UFLA & Gim5 & Zea mays & - & - & UFLA \\
\hline Gigasporaceae & Gigaspora rosea & A35 (IES-19) & Gir & - & IES $^{e}$ (Cuba) & - & CNPAB \\
\hline Gigasporaceae & Racocetra gregaria & 200-UFLA & $\mathrm{Rg}$ & Gossypium hirsutum & Flórida, EUA & - & UFLA \\
\hline Gigasporaceae & Scutellospora calospora & A80 (CNPAB 038) & Sc & Native plant & Oriximiná, PA & Amazon forest & CNPAB \\
\hline Gigasporaceae & Scutellospora heterogama & A34 (IES-16) & Sh1 & - & IES $^{e}($ Cuba $)$ & - & CNPAB \\
\hline Gigasporaceae & Scutellospora heterogama & A2 (CNPAB 002) & Sh2 & Coffea arabica & Campinas, SP & Atlantic forest & CNPAB \\
\hline Gigasporaceae & Scutellospora heterogama & 312-UFLA & Sh3 & - & Flórida, EUA & - & UFLA \\
\hline Gigasporaceae & Scutellospora heterogama & URM-FMA 05 & Sh4 & - & - & - & UFPE \\
\hline Gigasporaceae & Scutellospora heterogama & - & Sh5 & - & - & - & ESALq \\
\hline Gigasporaceae & Scutellospora pellucida & 464-UFLA & Sp1 & - & Lavras, MG & Cerrado & UFLA \\
\hline Gigasporaceae & Scutellospora pellucida & A70 (CNPAB 029) & $\mathrm{Sp} 2$ & Ipomoea batatas & Seropédica, RJ & Atlantic forest & CNPAB \\
\hline Gigasporaceae & Scutellospora pellucida & 128-UFLA & Sp3 & - & Lavras, MG & Cerrado & UFLA \\
\hline
\end{tabular}

a According to the species list available in http://schuessler.userweb.mwn.de/amphylo/accessed in June, 26 th 2013.

b Code of the isolates used in the institution of origin.

c Code of the isolates used in this work.

d Institutions that donated the isolates, FURB = Blumenau Regional University; CNPAB = Embrapa-National Center for Agrobiology Research; UFLA = Lavras Federal University; ESALQ = Luiz de Queiroz Superior School of Agriculture; UFPE = Pernambuco Federal University.

e Instituto de Ecologia y Sistematica de Cuba.

f International culture collections of (Vesicular) arbuscular fungi.

$\mathrm{g}$ Information not available on the institution of origin.

$\mathrm{h}$ This isolate was used only in the characterization, due to the unavailability of spores. 
environmental interferences associated with the origin of the isolates and to make the potential for infection uniform, all the isolates were multiplied simultaneously per six months in a greenhouse (Embrapa Agrobiology Research Center, Seropédica, RJ, Brazil), utilizing Urochloa decumbens (Stapf) R.D.Webster (syn. Brachiaria decumbens) as the host species, grown in pots containing $500 \mathrm{~mL}$ of autoclaved substrate. This substrate was composed by fractions of forest surface soil, a clayey soil (red-yellow Cambisol), and a sandy soil (Planosol) mixed in equal amounts (1:1:1 v:v:v). This substrate was autoclaved for $60 \mathrm{~min}$ at $120^{\circ} \mathrm{C}, 1.2 \mathrm{~kg} \mathrm{fm}^{-2}$ on two consecutive days, and remained at rest for 15 days in order to allow oxidation of possible soluble manganese. The chemical analysis revealed the following characteristics after autoclaving: $\mathrm{pH}$ in water $=4.8 ; \mathrm{Ca}^{2+}=1.3 \mathrm{cmol}_{\mathrm{C}} \mathrm{dm}^{-3} ; \mathrm{Mg}^{2+}=0.9 \mathrm{cmol}_{\mathrm{C}} \mathrm{dm}^{-3}$; $\mathrm{Al}^{3+}=0.3 \mathrm{cmol}_{\mathrm{c}} \mathrm{dm}^{-3} ; \mathrm{P}=5.2 \mathrm{mg} \mathrm{dm}^{-3}, \mathrm{~K}=32 \mathrm{mg} \mathrm{dm}^{-3}$ (Mehlich 1 ), and organic matter $=0.78 \mathrm{dag} \mathrm{kg}^{-1}$.

\subsection{Morphological characterization}

After six months of multiplication, the spores were extracted from $200 \mathrm{~mL}$ of soil by wet sieving (Gerdemann and Nicolson, 1963) and centrifuged in a water/sucrose solution (Jenkins, 1964). After extraction, the spores were selected under a stereoscopic microscope and mounted on slides with PVLG (polyvinyl-lacto-glycerol) and Melzer's reagent (1:1) (Brundrett et al., 1994). Confirmation of the identity of each isolate was performed by using the descriptions of morphological characteristics available in the INVAM (2012) and based on current species descriptions.

\subsection{Molecular characterization}

Spores were carefully selected for genotypic characterization under stereoscopic microscope regarding integrity, health, and purity. The selected spores were submitted to four ultrasound sessions of $15 \mathrm{~s}$, interspersed with washing in distilled sterile water to eliminate soil particles, and possible microorganisms adhering to their surface. The clean spores, apparently perfect and healthy, were then stored at $-20^{\circ} \mathrm{C}$.

\subsubsection{DNA extraction and PCR amplification}

The DNA extraction was performed as described by de Souza et al. (2004), by utilizing between 150 and 200 spores. For the PCR-RFLP analysis the DNA was amplified with the pair of primers NS1 (5'-GTAGTCATATGCTTGTCTC- $\left.3^{\prime}\right)$ and ITS4 $\left(5^{\prime}\right.$-TCCTCCGCTTATTGATATGC-3') (White et al., 1990), according to Novais et al. (2010). Then, with the primers NS31 (5'-TTGGAGGGCAAGTCTGGTGCC-3) (Simon et al., 1992) and F1Ra (5'-CTTTTACTTCCTCTAAATGACC-3') (de Souza et al., 2004), employing $2 \mu$ L of a dilution ( $1: 1000)$ from the first PCR as template, $200 \mu \mathrm{M}$ of each deoxyribonucleotide triphosphate (dNTP), $2.5 \mathrm{mM}$ of $\mathrm{MgCl}_{2}, 0.28 \mu \mathrm{M}$ of each primer, and $2.5 \mathrm{U}$ of Taq DNA polymerase (GoTAq Flexi DNA Polymerase-Promega, Madison, USA). The reaction was carried out in an Eppendorff ${ }^{\circledR}$ thermocycler with the following steps: $2 \mathrm{~min}$ at $93^{\circ} \mathrm{C}$ for initial denaturing, 30 cycles at $94{ }^{\circ} \mathrm{C}$ for $60 \mathrm{~s}, 55^{\circ} \mathrm{C}$ for $60 \mathrm{~s}, 72^{\circ} \mathrm{C}$ for $160 \mathrm{~s}$, and $72{ }^{\circ} \mathrm{C}$ for $5 \mathrm{~min}$.

\subsubsection{Analysis of PCR products by RFLP}

All PCR products were purified using the wizard SV gel and PCR clean-up system (Promega). The DNA fragments (NS31-F1Ra) were cleaved with the endonucleases Hinfl, TaqI, and MspI, using $8 \mu \mathrm{L}$ of the product from the second PCR, $1.5 \mu \mathrm{L}$ of the buffer (10X), and $4 \mathrm{U}$ of the enzyme, in a final volume of $15 \mu \mathrm{L}$. The cleavage was performed for $240 \mathrm{~min}$ at $37^{\circ} \mathrm{C}$. The fragments were then separated in agarose gel $(3 \% \mathrm{w} / \mathrm{v})$ for $150 \mathrm{~min}$ at $85 \mathrm{~V}$. The band profiles obtained were submitted to cluster analysis with the Gelcompar
II program (Applied Maths, Kortrijk, Belgium), adopting the Dice similarity coefficient and the UPGMA algorithm.

\subsubsection{Cloning of PCR products, sequencing, and phylogenetic analysis}

Purified PCR products were cloned using the $\mathrm{PGEM}^{\circledR}$-T easy vector system I and transformed into Escherichia coli (JM109 Compe-

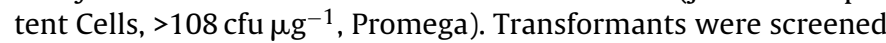
on Luria-Bertani ampicillin agar plates using the blue-white phenotype. Recombinant plasmids were isolated, screened for inserts by PCR, using the pGEM-F3000 (ACTATAGGGCGAATTGGG)-pGEMR208 (GGATAACAATTTCACACAGG) primers. The resulting PCR products were purified, quantified, and sequenced at Macrogen Inc. (Seoul, Republic of Korea). The sequences obtained were compared to the available sequences of the National Center for Biotechnology Information (NCBI) by using the basic local alignment search tool (BLAST) (Altschul et al., 1990, 1997). Sequences were aligned by using the SINA sequence alignment (Pruesse et al., 2012) and edited with ARB (Ludwig et al., 2004). The evolutionary history was inferred using the neighbor-joining (Saitou and Nei, 1987) and minimum evolution (Rzhetsky and Nei, 1992) methods and, as substitution model, the Kimura-2-parameter method (Kimura, 1980). All positions containing gaps and missing data were eliminated from the analysis. Bootstrap analysis was performed with 2000 replications. There were a total of 1866 positions in the final dataset. Phylogenetic analyses were conducted in MEGA5. The nucleotide sequences generated in this study were deposited in Gen Bank under accession numbers KF412622 to KF412638.

\subsection{Functional variability of different isolates of the AMF}

We selected 41 isolates that presented multiplication of sufficient spores for an evaluation of their functional variability in symbiosis with corn (Table 1 ). The test plant was corn (Zea mays L.; Poaceae, simple hybrid BRS 1010). The seeds were pre-germinated in a sterile substrate containing sand and vermiculite $(1: 1 \mathrm{v} / \mathrm{v})$ and when the radicles reached $10 \mathrm{~mm}$, three seedlings were transplanted to pots containing $3 \mathrm{~kg}$ of the same substrate described previously. The plants were culled after 15 days, leaving one plant per pot.

The plant roots were inoculated with a suspension containing 200 spores of each AMF isolate at the time of transplanting. The pots of the treatment without inoculation (control) received $5 \mathrm{~mL}$ of a filtrate containing no AMF propagules, prepared with a mixture of the inocula of the 41 isolates tested. The experimental design was randomized blocks with 42 treatments ( 41 isolates and the control without inoculation) and five replicates.

During the experiment, the plants were fertilized using nutrient solution of Hoagland without P, modified by Jarstfer and Sylvia (1995), composed of $6.39 \mathrm{mg} \mathrm{dm}^{-3}$ of $\mathrm{N}, 5.88 \mathrm{mg} \mathrm{dm}^{-3}$ of $\mathrm{K}, 6.01 \mathrm{mg} \mathrm{dm}^{-3}$ of $\mathrm{Ca}, 1.46 \mathrm{mg} \mathrm{dm}^{-3}$ of $\mathrm{Mg}, 4.33 \mathrm{mg} \mathrm{dm}^{-3}$ of $\mathrm{S}$, $0.02 \mathrm{mg} \mathrm{dm}^{-3}$ of $\mathrm{B}, 0.006 \mathrm{mg} \mathrm{dm}^{-3}$ of $\mathrm{Cu}, 0.002 \mathrm{mg} \mathrm{dm}^{-3}$ of $\mathrm{Zn}$, $0.17 \mathrm{mg} \mathrm{dm}^{-3}$ of Fe, $0.0002 \mathrm{mg} \mathrm{dm}^{-3}$ of $\mathrm{Mo}, 0.07 \mathrm{mg} \mathrm{dm}^{-3}$ of $\mathrm{Na}$, and $5.34 \mathrm{mg} \mathrm{dm}^{-3}$ of $\mathrm{Cl}$, divided in 20 applications, one per week in the first 45 days and then two per week until the end of the experiment.

After 100 days of growth, the following parameters were evaluated: (a) $P$ leaf content, measured in $0.8 \mathrm{~cm}$ diameter disks taken from the youngest fully developed leaf (Aziz and Habte, 1987); (b) plant height; (c) stem diameter; (d) shoot dry mass; (e) root colonization (Giovannetti and Mosse, 1980) determined after clarification and staining the root system (Grace and Stribley, 1991; Koske and Gemma, 1989), and (f) number of spores in $25 \mathrm{~mL}$ of substrate. The data were submitted to analysis of variance and Scott-Knott test (5\%), carried out in the SISVAR statistical program (Ferreira, 2008), after transforming the mycorrhizal colonization 
values and number of spores by $\arcsin (x / 100)^{1 / 2}$ and $(x+1)^{1 / 2}$, respectively. The variables shoot dry mass (SDM) and leaf $P$ content together were submitted to cluster analysis with the euclidean distance and the UPGMA method.

\section{Results}

\subsection{Morphological characterization}

We evaluated the morphology of spores of 42 arbuscular mycorrhizal fungi isolates based on the descriptions available in the INVAM and on the original description of each species. These isolates were classified into 20 species, distributed into 6 genera (Table 1). No differences were observed among geographical isolates of the same species based on this characterization.

\section{2. $P C R$ amplification and restriction analysis}

Amplification of DNA of isolates of arbuscular mycorrhizal fungi using the primer pairs NS1-ITS4 and NS31-F1Ra resulted in fragments of approximately $2.300 \mathrm{pb}$ and 1.300 base pairs, respectively. We obtained PCR products of enough quality for restriction analysis of 26 isolates (Fig. 1).

The PCR-RFLP based on the ribosomal 18S rRNA gene was efficient to discriminate Glomus sensu strictu and Acaulospora from Gigaspora and Scutellospora. The cluster obtained (Fig. 1) was partially coherent with the species classification based on spore morphology. The isolates of $R$. clarus (Rc1, Rc3, Rc4, Rc5, and Rc6), and $R$. manihotis ( $\mathrm{Rm}$ ) clustered with $100 \%$ similarity. The isolate G. formosanum (Gf) was distant from this group, with only $44 \%$ similarity.

Another very distinct cluster was obtained with the isolates of the Gigaspora and Scutellospora. Isolates of these genera were grouped with over $84 \%$ similarity. However, the RFLP technique did not permit a clear separation of the species described based on their spore morphology. The Gigaspora-Scutellospora group contained five sub-groups, each of them with isolates having 100\% similarity: subgroups [Sh2 and Sc]; [Gia1, Gia2, Gic1, Gim3, Gim4, Gim6, Sp1, Sp3]; [Gim1, Gim2, Gisp, and Sh4]; [Gim5 and Gir]; and [Gic2].

The $A$. colombiana isolates differed sharply from each other, with the closest being Ac1 and Ac5, which presented 90\% similarity. Ac3 presented 60\% similarity with Ac1 and Ac5.

\subsection{Sequence analysis}

The $18 \mathrm{~S}$ rRNA genes of 17 isolates were successfully sequenced and used for phylogenetic analysis. The trees were calculated by two different methods-neighbor-joining and minimum evolution-presenting a similar topology. Thus, only the neighborjoining tree is shown (Fig. 2).

Three major clades with high bootstrap support ( $>75 \%$ ), which included sequences of the families Glomeraceae, Acaulosporaceae, and Gigasporaceae, were formed. The formation of clades by genus also presented a considerable support $(>50 \%)$ and the position of sequences within these clades agreed with the morphological classification, although we generally could not clearly differentiate between species belonging to the same genus based on the $18 \mathrm{~S}$ rDNA. Rhizophagus clarus and Gigaspora margarita, on the other hand, could be clearly differentiated with a high bootstrap support, except for one sequence that was clustered apart from other Rhizophagus clarus sequences. The distribution of sequences within the clades agrees with the PCR-RFLP analysis, which divided the sequences into clusters according to family and genus.

\subsection{Functional variability different isolates of the AMF}

There were significant effects $(p<0.05)$ from the inoculation with the AMF isolates on the growth, nutrition, and mycorrhization




analysis was performed with the Dice similarity coefficient and the UPGMA algorithm. 
Table 2

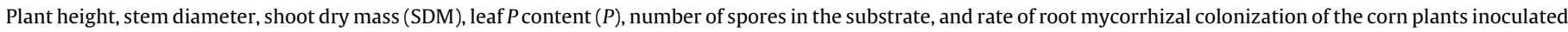
with the arbuscular mycorrhizal fungi isolates from different origins.

\begin{tabular}{|c|c|c|c|c|c|c|c|}
\hline Code & Treatments & $\begin{array}{l}\text { Height } \\
\mathrm{cm}\end{array}$ & $\begin{array}{l}\text { Diameter } \\
\mathrm{mm}\end{array}$ & $\begin{array}{l}\text { SDM } \\
\mathrm{g}\end{array}$ & $\begin{array}{l}P \\
\mathrm{~g} \mathrm{~kg}^{-1}\end{array}$ & $\begin{array}{l}\text { Spores }^{a} \\
\text { unit }\end{array}$ & $\begin{array}{l}\text { Colonization } \\
\%\end{array}$ \\
\hline Con & Control (not inoculated) & $24.9 \mathrm{c}$ & $5.68 \mathrm{c}$ & $1.95 \mathrm{~b}$ & $3.17 \mathrm{~b}$ & $1.0 \mathrm{~d}$ & $0.0 \mathrm{c}$ \\
\hline Ac1 & A. colombiana (A87) & $29.3 \mathrm{~b}$ & $5.01 \mathrm{c}$ & $1.68 \mathrm{c}$ & $3.45 \mathrm{~b}$ & $25.0 \mathrm{c}$ & $26.0 \mathrm{~b}$ \\
\hline Ac2 & A. colombiana (A15) & $32.1 \mathrm{~b}$ & $5.15 \mathrm{c}$ & $2.49 \mathrm{a}$ & $3.18 \mathrm{~b}$ & $33.7 \mathrm{c}$ & $33.4 \mathrm{~b}$ \\
\hline Ac3 & A. colombiana (ALCOA-CCB2) & $35.7 \mathrm{a}$ & $5.36 \mathrm{c}$ & $2.91 \mathrm{a}$ & $3.85 \mathrm{a}$ & $64.3 \mathrm{a}$ & $51.8 \mathrm{a}$ \\
\hline Ac4 & A. colombiana (06-UFLA) & $36.0 \mathrm{a}$ & $5.83 \mathrm{~b}$ & $2.41 \mathrm{~b}$ & $4.65 \mathrm{a}$ & $59.4 \mathrm{a}$ & $51.2 \mathrm{a}$ \\
\hline Ac5 & A. colombiana (AMZ570A) & $36.0 \mathrm{a}$ & $6.25 \mathrm{a}$ & $2.69 \mathrm{a}$ & $4.15 \mathrm{a}$ & $76.2 \mathrm{a}$ & $29.0 \mathrm{~b}$ \\
\hline Am & A. morrowiae (401-UFLA) & $45.7 \mathrm{a}$ & $6.22 \mathrm{a}$ & $3.08 \mathrm{a}$ & $3.89 \mathrm{a}$ & $67.3 \mathrm{a}$ & $58.4 \mathrm{a}$ \\
\hline As1 & A. scrobiculata (A38) & 29.4 b & $5.52 \mathrm{c}$ & $2.35 \mathrm{~b}$ & $3.22 \mathrm{~b}$ & $27.6 \mathrm{c}$ & $43.0 \mathrm{a}$ \\
\hline As2 & A. scrobiculata (ALCOA29) & $19.6 \mathrm{c}$ & $4.85 \mathrm{c}$ & $1.28 \mathrm{c}$ & $2.67 \mathrm{~b}$ & $15.7 \mathrm{~d}$ & $43.2 \mathrm{a}$ \\
\hline Asp & A. spinosa (95-UFLA) & $30.5 \mathrm{~b}$ & $5.38 \mathrm{c}$ & $2.22 \mathrm{~b}$ & $3.51 \mathrm{~b}$ & $10.8 \mathrm{~d}$ & $27.0 \mathrm{~b}$ \\
\hline Aca & Acaulospora sp. (A88) & $43.9 \mathrm{a}$ & $5.35 \mathrm{c}$ & $2.74 \mathrm{a}$ & $3.84 a$ & $35.4 \mathrm{c}$ & $31.8 \mathrm{~b}$ \\
\hline Ce1 & C. etunicatum (365-UFLA) & $16.4 \mathrm{c}$ & $5.17 \mathrm{c}$ & $0.99 \mathrm{c}$ & $2.51 \mathrm{~b}$ & $10.4 \mathrm{~d}$ & $38.2 \mathrm{~b}$ \\
\hline $\mathrm{Ce} 2$ & C. etunicatum (URM-FMA 03) & $31.6 \mathrm{~b}$ & $5.00 \mathrm{c}$ & $2.31 \mathrm{~b}$ & $3.16 \mathrm{~b}$ & $36.4 \mathrm{c}$ & $31.8 \mathrm{~b}$ \\
\hline $\mathrm{Ce} 3$ & C. etunicatum (ESALq) & $32.1 \mathrm{~b}$ & $5.55 \mathrm{c}$ & $2.58 \mathrm{a}$ & $3.36 \mathrm{~b}$ & $28.7 \mathrm{c}$ & $27.8 \mathrm{~b}$ \\
\hline $\mathrm{Ce} 4$ & C. etunicatum (SCT101A) & $44.1 \mathrm{a}$ & $6.51 \mathrm{a}$ & $3.29 \mathrm{a}$ & $3.71 \mathrm{a}$ & $52.4 \mathrm{~b}$ & $58.6 \mathrm{a}$ \\
\hline Gf & G. formosanum (A20) & $28.4 \mathrm{~b}$ & $5.56 \mathrm{c}$ & $1.94 \mathrm{~b}$ & $2.96 \mathrm{~b}$ & $42.0 \mathrm{~b}$ & $57.2 \mathrm{a}$ \\
\hline Rc1 & R. clarus (A5) & $28.6 \mathrm{~b}$ & $5.01 \mathrm{c}$ & $1.97 \mathrm{~b}$ & $3.27 \mathrm{~b}$ & $38.8 \mathrm{~b}$ & $40.0 \mathrm{~b}$ \\
\hline Rc2 & R. clarus (URM-FMA 08) & 34.9 a & $6.78 \mathrm{a}$ & $3.51 \mathrm{a}$ & $4.45 \mathrm{a}$ & $47.5 \mathrm{~b}$ & $50.6 \mathrm{a}$ \\
\hline Rc3 & R. clarus (CMM-306) & $40.0 \mathrm{a}$ & $5.85 \mathrm{~b}$ & $3.13 \mathrm{a}$ & $3.94 a$ & $43.8 \mathrm{~b}$ & $52.8 \mathrm{a}$ \\
\hline Rc4 & R. clarus (ESALq) & $40.6 \mathrm{a}$ & $6.59 \mathrm{a}$ & $3.40 \mathrm{a}$ & $3.87 \mathrm{a}$ & $61.1 \mathrm{a}$ & $54.6 \mathrm{a}$ \\
\hline Rc5 & R. clarus (351-UFLA) & $45.0 \mathrm{a}$ & $6.76 \mathrm{a}$ & $3.27 \mathrm{a}$ & $4.28 \mathrm{a}$ & $46.5 \mathrm{~b}$ & $50.6 \mathrm{a}$ \\
\hline Rc6 & R. clarus (A90) & $43.1 \mathrm{a}$ & $6.26 \mathrm{a}$ & $3.36 \mathrm{a}$ & $4.29 \mathrm{a}$ & $51.3 \mathrm{~b}$ & $27.2 \mathrm{~b}$ \\
\hline $\mathrm{Rm}$ & R. manihotis (A83) & $34.4 \mathrm{a}$ & $6.36 \mathrm{a}$ & $2.93 \mathrm{a}$ & $4.97 \mathrm{a}$ & $44.4 \mathrm{~b}$ & $42.8 \mathrm{a}$ \\
\hline Gia1 & Gi. albida (URM-FMA 01) & $39.8 \mathrm{a}$ & $5.21 \mathrm{c}$ & $2.76 \mathrm{a}$ & $3.88 \mathrm{a}$ & $32.1 \mathrm{c}$ & $50.6 \mathrm{a}$ \\
\hline Gia2 & Gi. albida (03-UFLA MG) & $29.8 \mathrm{~b}$ & $5.64 \mathrm{c}$ & $2.06 \mathrm{~b}$ & $3.29 \mathrm{~b}$ & $22.2 \mathrm{c}$ & $34.8 \mathrm{~b}$ \\
\hline Gic1 & Gi. candida (A36) & $22.6 \mathrm{c}$ & $5.68 \mathrm{c}$ & $1.96 \mathrm{~b}$ & $3.64 \mathrm{~b}$ & $17.7 \mathrm{~d}$ & $29.8 \mathrm{~b}$ \\
\hline Gim1 & Gi. margarita (A49) & $19.7 \mathrm{c}$ & $5.32 \mathrm{c}$ & $1.67 \mathrm{c}$ & $3.47 \mathrm{~b}$ & $8.0 \mathrm{~d}$ & $40.2 \mathrm{~b}$ \\
\hline $\operatorname{Gim} 2$ & Gi. margarita (A1) & $32.2 \mathrm{~b}$ & $5.58 \mathrm{c}$ & $2.05 \mathrm{~b}$ & $3.30 \mathrm{~b}$ & $9.4 \mathrm{~d}$ & $38.6 \mathrm{~b}$ \\
\hline $\operatorname{Gim} 3$ & Gi. margarita (A41) & $33.0 \mathrm{~b}$ & $5.87 \mathrm{~b}$ & $2.82 \mathrm{a}$ & $3.49 \mathrm{~b}$ & $14.1 \mathrm{~d}$ & $48.0 \mathrm{a}$ \\
\hline Gim4 & Gi. margarita (279-UFLA) & $36.5 \mathrm{a}$ & $4.96 \mathrm{c}$ & $2.50 \mathrm{a}$ & $3.85 \mathrm{a}$ & $16.6 \mathrm{~d}$ & $51.8 \mathrm{a}$ \\
\hline Gim5 & Gi. margarita (R1 UFLA) & 39.9 a & $5.47 \mathrm{c}$ & $3.08 \mathrm{a}$ & $3.93 \mathrm{a}$ & $23.7 \mathrm{c}$ & $47.6 \mathrm{a}$ \\
\hline Gir & Gi. rosea $(\mathrm{A} 35)$ & $38.7 \mathrm{a}$ & $5.80 \mathrm{~b}$ & $2.35 \mathrm{~b}$ & $4.48 \mathrm{a}$ & $32.9 \mathrm{c}$ & $41.8 \mathrm{a}$ \\
\hline $\operatorname{Rg}$ & R. gregaria (200-UFLA) & $30.0 \mathrm{~b}$ & $4.76 \mathrm{c}$ & $2.00 \mathrm{~b}$ & $3.36 \mathrm{~b}$ & $10.7 \mathrm{~d}$ & $25.0 \mathrm{~b}$ \\
\hline Sc & S. calospora (A80) & $38.5 \mathrm{a}$ & $6.62 \mathrm{a}$ & $3.44 \mathrm{a}$ & $4.07 \mathrm{a}$ & $48.4 \mathrm{~b}$ & $49.6 \mathrm{a}$ \\
\hline Sh1 & S. heterogama (A34) & $25.1 \mathrm{c}$ & $4.62 \mathrm{c}$ & $1.96 \mathrm{~b}$ & $3.00 \mathrm{~b}$ & $16.2 \mathrm{~d}$ & $30.4 \mathrm{~b}$ \\
\hline Sh2 & S. heterogama (A2) & $35.7 \mathrm{a}$ & $5.90 \mathrm{~b}$ & $2.88 \mathrm{a}$ & $3.82 \mathrm{a}$ & $20.5 \mathrm{~d}$ & $53.0 \mathrm{a}$ \\
\hline Sh3 & S. heterogama (312-UFLA) & $39.5 \mathrm{a}$ & $6.04 \mathrm{~b}$ & $2.73 \mathrm{a}$ & $4.33 \mathrm{a}$ & $32.8 \mathrm{c}$ & $60.4 \mathrm{a}$ \\
\hline Sh4 & S. heterogama (URM-FMA 05) & $40.4 \mathrm{a}$ & $5.52 \mathrm{c}$ & $2.72 \mathrm{a}$ & $3.83 \mathrm{a}$ & $30.6 \mathrm{c}$ & $55.0 \mathrm{a}$ \\
\hline Sh5 & S. heterogama (ESALq) & $42.2 \mathrm{a}$ & $5.30 \mathrm{c}$ & $3.00 \mathrm{a}$ & $3.84 \mathrm{a}$ & $29.8 \mathrm{c}$ & $51.0 \mathrm{a}$ \\
\hline Sp1 & S. pellucida (464-UFLA) & $28.5 \mathrm{~b}$ & $5.02 \mathrm{c}$ & $2.17 \mathrm{~b}$ & $3.31 \mathrm{~b}$ & $14.3 \mathrm{~d}$ & $24.6 \mathrm{~b}$ \\
\hline Sp2 & S. pellucida (A70) & $28.8 \mathrm{~b}$ & $4.90 \mathrm{c}$ & $1.84 \mathrm{~b}$ & $3.54 \mathrm{~b}$ & $22.2 \mathrm{c}$ & $31.8 \mathrm{~b}$ \\
\hline Sp3 & S. pellucida (128-UFLA) & $45.9 \mathrm{a}$ & $5.64 \mathrm{c}$ & $2.77 \mathrm{a}$ & $3.84 \mathrm{a}$ & $21.4 \mathrm{c}$ & $61.6 \mathrm{a}$ \\
\hline
\end{tabular}

a Values transformed by $(x+1)^{1 / 2}$; different letters in the column indicate differences of the means by the Scott-Knott test at $5 \%$.

of corn (Table 2). These effects differed between isolates of distinct species as well as between isolates of the same species, showing no correlation between the ability to promote plant growth with the genus, the species or the origin of the isolates.

These isolates were clustered in two main groups based on shoot dry mass (SDM) and leaf $P$ of corn plants. One of the groups contains isolates that are efficient in promoting growth and phosphate nutrition, while isolates considered inefficient were separated in another group (Fig. 3).

The isolates A. colombiana (Ac3, Ac4, and Ac5), A. morrowiae (Am2), Acaulospora sp. (Aca), C. etunicatum (Ce4), R. clarus (Rc2, Rc3, Rc4, Rc5, and Rc6), R. manihotis (Rm), Gi. albida (Gia1), Gi. margarita (Gim4 and Gim5), Gi. rosea (Gir), S. calospora (Sc), S. heterogama (Sh2, Sh3, Sh4, and Sh5), and S. pellucida (Sp3) promoted greater height and leaf $P$ content (Table 2 ). In general, these isolates also promoted an increase in shoot dry mass and stem diameter, which can be observed from the high average values (Table 2) and from the positive correlations between leaf $P$ content and plant height $(r=0.69 ; P \leq 0.01)$, shoot dry mass $(r=0.72 ; P \leq 0.01)$, and stem diameter $(r=0.65 ; P \leq 0.01)$.

Within the same fungal species, the isolates that presented greater root colonization and sporulation improved $P$ nutrition and promoted better plant growth. This can be observed for the isolates
A. colombiana (Ac3, Ac4, and Ac5), A. scrobiculata (As1), C. etunicatum (Ce4), R. clarus (Rc2, Rc3, Rc4, and Rc5), Gi. albida (Gia1), Gi. margarita (Gim3, Gim4, and Gim5), S. heterogama (Sh2, Sh3, Sh4, and Sh5), and S. pellucida (Sp3) (Table 2). The functional variability was lower among isolates of R. clarus, S. Heterogama, and A. scrobiculata, with most of the isolates promoting similar responses. For example, among the isolates by Rc1, Rc3, Rc4, Rc5, and Rc6, only Rc1 was inefficient for corn (Fig. 3).

\section{Discussion}

In the present study, we examined the taxonomical classification and functional variability of a large collection of tropical AMF isolates by morphological and molecular characterization, and measured the accumulation of shoot dry mass and phosphorus in plants of corn (Zea mays L.). The 41 AMF-plant combinations examined had responses ranging from functionally compatible interactions, to essentially neutral (i.e., similar to the treatment without inoculation), as measured by shoot growth and leaf $P$ content of corn plants.

The first step was to characterize our AMF collection by using both morphological and molecular methods. Since the morphology of spores may not reflect their genetic condition (Oehl et al., 2011), 


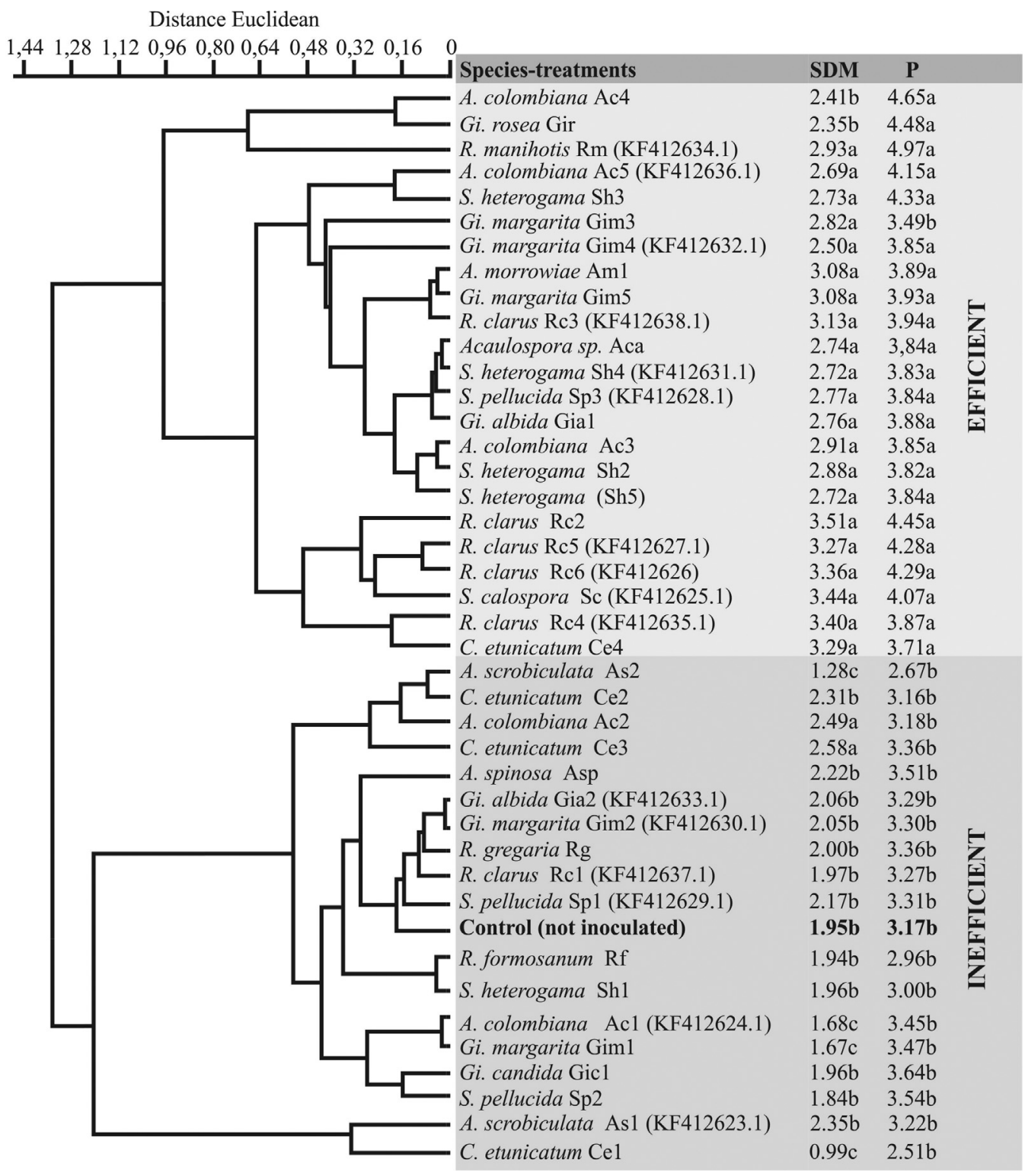

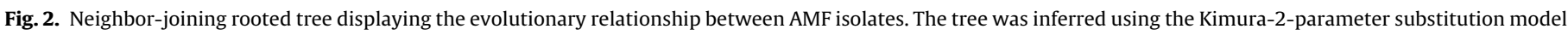
and 2000 bootstrap replicates. There were a total of 1866 positions in the final dataset.

the molecular characterization was included in order to evaluate the accuracy of the morphological characterization.

We found out a high diversity of fungi in the collection, with species belonging to the families Acaulosporaceae, Claroideoglomeraceae, Gigasporaceae, and Glomeraceae (Table 1). Even though, the molecular characterization based on 18S rRNA did not have a sufficient resolution to differentiate fungal isolates at the species level (Schoch et al., 2012), it was robust enough to confirm the characterization at the genus level. The sequencing of 17 isolates confirmed the morphological characterization of the isolates. When used in BLAST searches, the sequences matched the corresponding published sequences of species with high homology values.

Both sequencing and PCR-RFLP agreed, confirming the PCR-RFLP as a tool to obtaining a rapid identification of introduced or naturally occurring AMF in association with economically important plant species (Redecker et al., 2000; Smith and Read, 2008). The molecular technique applied was relatively successful, showing that the gene sequences are heterogeneous among isolates of Rhizophagus, Gigasporaceae, and Acaulospora. The restriction band profiles also confirmed the identification of $R$. clarus, A. colombiana, and the majority of the members of the Gigasporaceae family, but did not permit distinguishing the species of this family. Restriction band profiles are more useful to identify taxonomic entities at the species level in other organisms than in Glomeromycota (Redecker et al., 1997), possibly because these fungi have different copies of the region of the ribosomal DNA in a single spore.

Zea mays L. behaved as a typical mycorrhiza-responsive plant species, having relatively high levels of root colonization, and considerable growth benefits as measured by shoot growth and leaf $P$ content. The data demonstrate the functional variability among the isolates studied, with variation in fungus-plant compatibility and efficiency in promoting growth and nutrition of corn. For the majority of isolates there is a positive relationship between mycorrhizal root colonization, corn growth, and $P$ nutrition. However, there are isolates that exclusively colonize corn roots without any compensation in growth and P nutrition, as already mentioned for the case of $R$. formosanum (Rf), as well as the lineages Gi. margarita (Gim3) and A. scrobiculata (As1 and As2) which supports previous findings that mycorrhizal function is not linked to the degree of colonization (Burleigh et al., 2002; Graham and Eissenstat, 1998). 


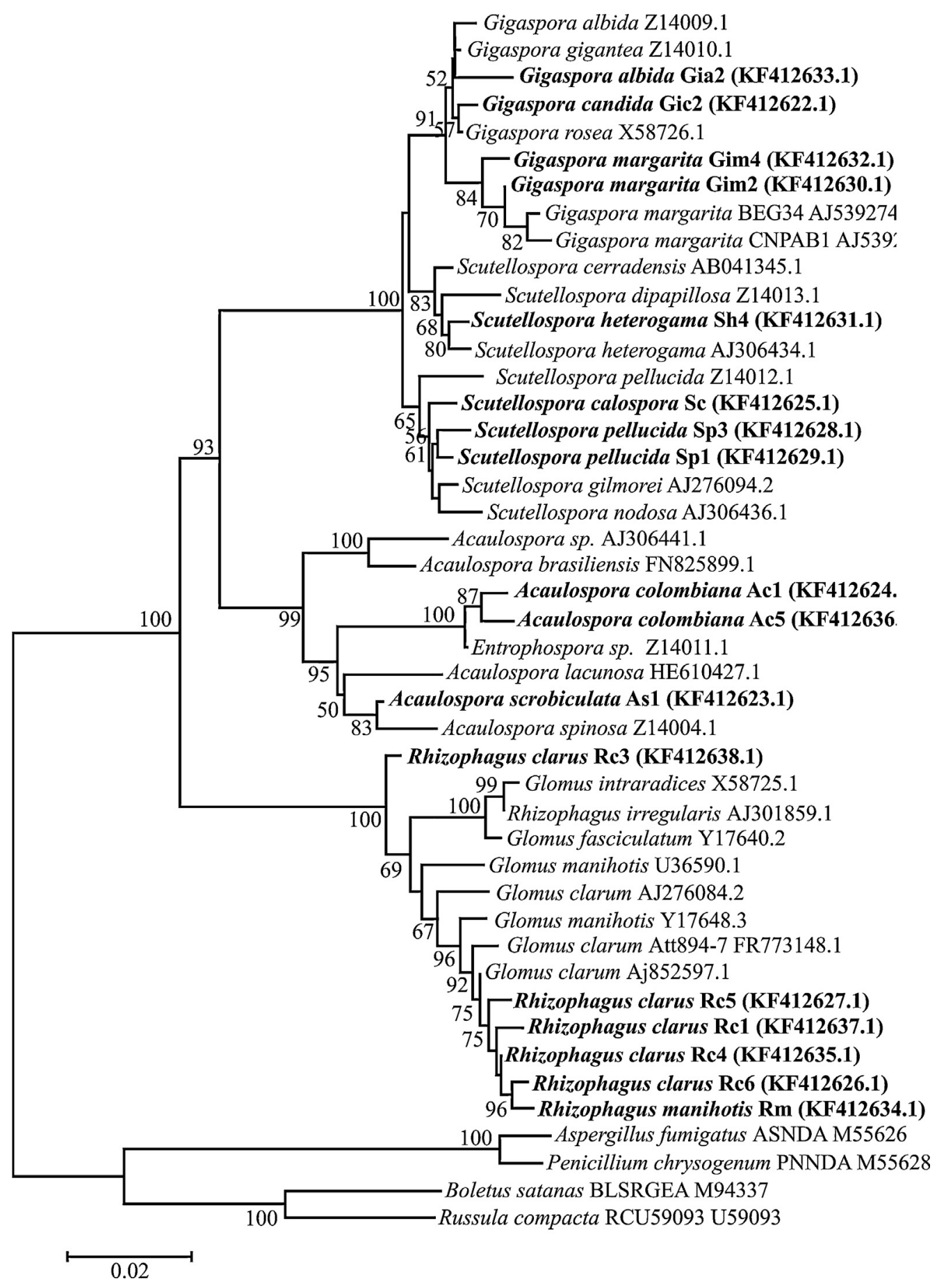

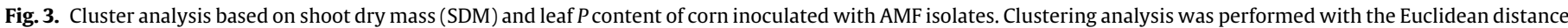
and the UPGMA algorithm.

This situation suggests that various mechanisms act on the different corn-fungus combinations, so that the most efficient symbiosis (from a farming standpoint) is the one with the best fit between the investment the plant makes in intraradical colonization and the return that the plant obtains in growth and nutrition (Koide, 1991). Further according to that author, this can be influenced by the development characteristics of each isolate, which are peculiar and intrinsic to its genetic expression, associated with corn and the substrate used. The particular behavior of corn regarding susceptibility to colonization by different isolates appears to result both from the fungus-plant compatibility, as shown by Pouyu-Rojas et al. (2006), and the capacity of each isolate to overcome the barriers to root colonization (Kiriachek et al., 2009).

AMF have different strategies for root colonization, which may be related to taxonomic differences at the family level. It is believed that Glomeraceae e Acaulosporaceae are highly infective due to their delicate hyphae with ordained growth, thus colonizing plant roots quickly, but with low ability to explore the soil. On the other hand, Gigasporaceae tend to have robust hyphae, densely aggregated, colonizing plants slowly, but with a greater ability to explore the soil matrix, thus forming a more extensive mycelial net (Hart and Reader, 2001; Jakobsen et al., 1992; Smith et al., 2000). These 
differences may be a consequence of hyphae longevity: delicate hyphae may be more ephemera. This character is also linked to the ability to provide roots with $\mathrm{P}$ and to protect roots from soil pathogens. It is also suggested that fungi that colonize preferentially the interior of roots, as the Glomeraceae, are better on protecting roots from pathogens, while Gigasporaceae are better in exploring the soil for nutrients (Maheralis and Klironomos, 2007). However, this was not evident for our isolates, since the ability to promote plant growth was unrelated to the taxonomical position of the isolates. In fact, Glomus isolates were effective with corn, with one exception (Table 2).

Munkvold et al. (2004) studying different geographic isolates of the species Glomus mosseae, Glomus caledonium, and Glomus claroideum, found that although species clusters have been clearly distinguished by analysis of LSU rDNA sequences, these groups often do not correspond to the functional differences observed. The authors noted that the important functional characteristics, such as hyphae length, plant growth, and P nutrition, varied more between the isolates of the same species than between species, suggesting the need for simultaneous analysis of various molecular markers to explain these functional differences. Functional difference in isolates can be induced by selective pressure in only a few generations, as reported by Koch et al. (2004). Employing the PCRAFLP (amplified fragment length polymorphism) technique, they observed genetic differences between Glomus intraradices isolates from a single geographic area after field experiments over several generations with part of the community maintained in a separate place but under identical conditions. The isolates showed considerable differences in the band profiles and phenotypes, especially in the density of the extraradical hyphae, a characteristic considered important in the acquisition of phosphorous from the soil. The genetic diversity of AMF has allowed them to thrive over millions of years in different land ecosystems with a wide diversity of plants in constant change over the time.

Several authors reported variability in the symbiotic efficiency of AMF isolates (Feddermann et al., 2010; Lerat et al., 2003; Li et al., 2008; Pringle and Bever, 2008). Lerat et al. (2003) reported that AMF could differ in the amount of carbon allocated to them. In addition, it has also been reported that there is variation in the amount of mineral nutrients provided by AMF (Ravnskov and Jakobsen, 1995; Smith et al., 2004). Functional variability of AMF is observed in the nutrient balance as well as in the protective effects of AM fungi with regard to biotic or abiotic stress (Fester and Sawers, 2011; Kelly et al., 2005; Lerat et al., 2003; Ravnskov and Jakobsen, 1995; Sikes et al., 2009; Smith et al., 2004) and in their positive impact on soil aggregate stability (Piotrowski et al., 2004). However, studies of the intraspecific functional variability have been carried out with only a small number of isolates and few AMF species, most often with different Funneliformis mosseae isolates.

In the present study, we examined a large number of tropical AMF isolates and observed that the differences, both genotypic and functional, are often greater between isolates of the same species than between different species defined based on spore morphology. The results reported here are important to provide greater insight into the functional variability of AMF.

\section{Conclusion}

This study contributes to improve the comprehension of the functional variability of AMF and shows that the same host plant can respond in different ways to AMF inoculation at the level of colonization, P uptake, and translocation and growth. The isolates analyzed could be grouped into efficient and inefficient promoters of growth, phosphate nutrition, and mycorrhization of corn independent of their geographical location. Functional differences can be greater between isolates of the same species than between isolates of distinct species. Physiological responses were related to the ability of the fungi to provide $P$ to the host in $92.68 \%$ of the fungus-plant combinations tested in this study. Besides, $R$. clarus and $S$. heterogama isolates were consistently efficient in promoting corn growth.

\section{Acknowledgments}

We thank the researchers Leonor Costa Maia (Pernambuco Federal University), Elke J.B.N. Cardoso (ESALq), and Sidney Sturmer (FURB) and their respective institutions for providing some of the AMF lineages utilized in the present study; Samuel Ribeiro Passos for help with the Gelcompar II program; the CNPq and CAPES for individual support (Novais, C.B. and Borges, W.L. received a doctoral scholarship), and both Graduate Programs in Soil Science at UFLA and UFRRJ.

\section{References}

Altschul, S.F., Gish, W., Miller, W., Myers, E.W., Lipman, D.J., 1990. Basic local alignment search tool. J. Mol. Biol. 215, 403-410.

Altschul, S.F., Madden, T.L., Schäffer, A.A., Zhang, J., Zhang, Z., Miller, W., Lipman, D.J., 1997. Gapped BLAST and PSI-BLAST: a new generation of protein database search programs. Nucleic Acids Res. 25, 3389-3402.

Avio, L., Pellegrino, E., Bonari, E., Giovannetti, M., 2006. Functional diversity of arbuscular mycorrhizal fungal isolates in relation to extraradical mycelial networks. New Phytol. 172, 347-357.

Aziz, T., Habte, M., 1987. Determining vesicular-arbuscular mycorrhizal effectiveness by monitoring P status of leaf disks. Can. J. Microbiol. 33, 1097-1101.

Babu, A.G., Reddy, M.S., 2011. Diversity of arbuscular mycorrhizal fungi associated with plants growing in fly ash pond and their potential role in ecological restoration. Curr. Microbiol. 63, 273-280.

Brundrett, M., Melville, L., Peterson, L., 1994. Practical Methods in Mycorrhizal Research. Mycologue Publications, Guelph.

Burleigh, S.H., Cavagnaro, T., Jakobsen, I., 2002. Functional diversity of arbuscular mycorrhizas extends to the expression of plant genes involved in P nutrition. J. Exp. Bot. 53, 1593-1601

de Souza, F.A., Kowalchuk, G.A., Leeflang, P., van Veen, J.A., Smith, E., 2004. PCRdenaturing gradient gel electrophoresis profiling of inter- and intraspecies $18 \mathrm{~S}$ rRNA gene sequence heterogeneity in an arbuscular mycorrhizal fungi of the genus Gigaspora. Appl. Environ. Microbiol. 70, 1413-1424.

Feddermann, N., Finlay, R., Boller, T., Elfstrand, M., 2010. Functional diversity in arbuscular mycorrhiza-the role of gene expression, phosphorous nutrition, and symbiotic efficiency. Fungal Ecol. 3, 1-8.

Ferreira, D.F., 2008. Sisvar: a program for statistical analysis and teaching. Rev. Symp. 6, 36-41.

Fester, T., Sawers, R., 2011. Progress and challenges in agricultural applications of arbuscular mycorrhizal fungi. Crit. Rev. Plant Sci. 30, 459-470.

Gerdemann, J.N., Nicolson, T.H., 1963. Spores of mycorrhizal endogone species extracted from spil by wet-sieving and decanting. Trans. Brit. Mycol. Soc. 46, 235-244.

Giovannetti, M., Mosse, B., 1980. An evaluation of techniques to measure vesiculararbuscular mycorrhizal infection on roots. New Phytol. 84, 489-500.

Grace, C., Stribley, D.P., 1991. A safer procedure for routine staining of vesiculararbuscular mycorrhizal fungi. Mycol. Res. 95, 1160-1162.

Graham, J.H., Eissenstat, D.M., 1998. Field evidence for the carbon cost of citrus mycorrhizas. New Phytol. 140, 103-110.

Hart, M.M., Reader, R.J., 2001. Taxonomic basis for variation in colonization strategy of arbuscular mycorrhizal fungi. New Phytol. 153, 335-344.

Husband, R., Herre, E.A., Turner, S.L., Gallery, R., Young, J.P.W., 2002. Molecular diversity of arbuscular mycorrhizal fungi and patterns of host association over time and space in a tropical forest. Mol. Ecol. 11, 2669-2678.

INVAM - International Culture Collection of Arbuscular \& Vesicular-Arbuscular Mycorrhizal Fungi. Available in <www.invam.caf.wvu.edu/index.html>. Accessed February 6, 2012.

Jakobsen, I., Abbott, L.K., Robson, A.D., 1992. External hyphae of vesicular-arbuscular mycorrhizal fungi associated with Trifolium subterraneum L. 2. Hyphal transport of ${ }^{32}$ P over defined distances. New Phytol. 120, 509-516.

Jarstfer, A.G., Sylvia, D.M., 1995. Aeroponic culture of VAM fungi. In: Varma, A., Hock, B. (Eds.), Mycorrhiza. Springer-Verlag, Heidelberg, pp. 427-441.

Jenkins, W.R., 1964. A rapid centrifugal-floration technique for separating nematodes from soil. Plant Dis. Rep. 48, 692.

Kelly, C.N., Morton, J.B., Cumming, J.R., 2005. Variation in aluminum resistance among arbuscular mycorrhizal fungi. Mycorrhiza 15, 193-201.

Kimura, M., 1980. A simple method for estimating evolutionary rate of base substitutions through comparative studies of nucleotide sequences. J. Mol. Evol. $16,111-120$.

Kiriachek, S.G., de Azevedo, L.C.B., Peres, L.E.P., Lambais, M.R., 2009. Regulation of arbuscular mycorrhizae development. Rev. Bras. Cienc. Solo 33, 1-16. 
Koch, A.M., Kuhn, G., Fontanillas, P., Fumagalli, L., Goudet, I., Sanders, I.R., 2004. High genetic variability and low local diversity in a population of arbuscular mycorrhizal fungi. Proc. Natl. Acad. Sci. USA 101, 2369-2374.

Koide, R.T., 1991. Nutrient supply, nutrient demand and plant response to mycorrhizal infection. New Phytol. 117, 365-386.

Koske, R.E., Gemma, J.N., 1989. A modified procedure for staining roots to detect VA mycorrhizas. Mycol. Res. 92, 486-488.

Lerat, S., Lapointe, L., Piche, Y., Vierheilig, H., 2003. Variable carbon-sink strength of different Glomus mosseae strains colonizing barley roots. Can. J. Bot. 81, 886-889.

Li, H., Smith, F.A., Dickson, S., Holloway, R.E., Smith, S.E., 2008. Plant growth depressions in arbuscular mycorrhizal symbioses: not just caused by carbon drain? New Phytol. 178, 852-862.

Ludwig, W., Strunk, O., Westram, R., Richter, L., Meier, H., Yadhukumar, Buchner, A., Lai, T., Steppi, S., Jobb, G., Förster, W., Brettske, I., Gerber, S., Ginhart, A.W., Gross, O., Grumann, S., Hermann, S., Jost, R., König, A., Liss, T., Lüßmann, R., May, M., Nonhoff, B., Reichel, B., Strehlow, R., Stamatakis, A., Stuckmann, N., Vilbig, A., Lenke, M., Ludwig, T., Bode, A., Schleifer, K., 2004. ARB: a software environment for sequence data. Nucleic Acids Res. 32, 1363-1371.

Maheralis, H., Klironomos, J.N., 2007. Influence of phylogeny on fungal community assembly and ecosystem functioning. Science 316, 1746-1748.

Martínez-García, L.B., Pugnaire, F.I., 2011. Arbuscular mycorrhizal fungi host preference and site effects in two plant species in a semiarid environment. Appl. Soil Ecol. 48, 313-317.

Martinez-García, L.B., Armas, C., de Dios Miranda, J., Padilla, F.M., Pugnaire, F.I., 2011. Shrubs influence arbuscular mycorrhizal fungi communities in a semi-arid environment. Soil Biol. Biochem. 43, 682-689.

Miras-Avalos, J.M., Antunes, P.M., Koch, A., Khosla, K., Klironomos, J.N., Dunfield, K.E., 2011. The influence of tillage on the structure of rhizosphere and root-associated arbuscular mycorrhizal fungal communities. Pedobiologia 54, 235-241.

Munkvold, L., Kjoller, R., Vestberg, M., Rosendahl, S., Jakobsen, I., 2004. High functional diversity within species of arbuscular mycorrhizal fungi. New Phytol. 164, 357-364.

Novais, C.B., de Souza, F.A., Siqueira, J.O., 2010. Phenotypic and molecular characterization of arbuscular mycorrhizal fungal spores from cultures maintained in germplasm collection. Pesqu. Agropecu. Bras. 45, 806-896.

Oehl, F., Sieverding, E., Palenzuela, J., Ineichen, K., da Silva, G.A., 2011. Advances in glomeromycota taxonomy and classification. IMA Fungus 2, 191-199.

Piotrowski, J.S., Denich, T., Klironomos, J.N., Graham, J.M., Rillig, M.C., 2004. The effects of arbuscular mycorrhizas on soil aggregation depend on the interaction between plant and fungal species. New Phytol. 164, 365-373.

Pouyu-Rojas, E., Siqueira, J.O., Santos, J.G.D., 2006. Symbiotic compatibility of arbuscular mycorrhizal fungi with tropical tree species. Rev. Bras. Cienc. Solo 30, 413-424.

Pringle, A., Bever, J.D., 2008. Analogous effects of arbuscular mycorrhizal fungi in the laboratory and a North Carolina field. New Phytol. 180, 162-175.
Pruesse, E., Peplies, J., Glöckner, F.O., 2012. SINA: accurate high-throughput multiple sequence alignment of ribosomal RNA genes. Bioinformatics 28, 1823-1829.

Ravnskov, S., Jakobsen, I., 1995. Functional compatibility in arbuscular mycorrhizas measured as hyphal P transport to the plant. New Phytol. 129, 611-618.

Redecker, D., Lodner, R., Graham, L.E., 2000. Glomalean fungi from the ordovician. Science 289, 1920-1921.

Redecker, D., Thierfelder, H., Walker, C., Werner, D., 1997. Restriction analysis of PCR-amplified internal transcribed spacers of ribosomal DNA as a tool for species identification in different genera of the order glomales. Appl. Environ. Microbiol. 63, 1756-1761.

Rzhetsky, A., Nei, M., 1992. A simple method for estimating and testing minimum evolution trees. Mol. Biol. Evol. 9, 945-967.

Saitou, N., Nei, M., 1987. The neighbor-joining method: a new method for reconstructing phylogenetic trees. Mol. Biol. Evol. 4, 406-425.

Schoch, C.L., Seifert, K.A., Huhndorf, S., Robert, V., Spouge, J.L., Levesque, A., Chen, W. 2012. Nuclear ribosomal internal transcribed spacer (ITS) region as a universal DNA barcode marker for fungi. Proc. Natl. Acad. Sci. USA 109, 6241-6246.

Schüßler, A., Walker, C., 2010. The Glomeromycota: a species list with new families and new genera. Available in <www.amf-phylogeny.com>. Accessed February $6,2012$.

Sikes, B.A., Cottenie, K., Klironomos, J.N., 2009. Plant and fungal identity determines pathogen protection of plant roots by arbuscular mycorrhizas. J. Ecol. 97, 1274-1280.

Simon, L., Lalonde, M., Bruns, T.D., 1992. Specific amplification of $18 \mathrm{~S}$ fungal ribosomal genes from vesicular-arbuscular endomycorrhizal fungi colonizing roots. Appl. Environ. Microbiol. 58, 291-295.

Smith, F.A., Jakobsen, I., Smith, S.E., 2000. Spatial differences in acquisition of soil phosphate between two arbuscular mycorrhizal fungi in symbiosis with Medicago truncatula. New Phytol. 147, 357-366.

Smith, S.E., Read, D.J., 2008. Mycorrhizal Symbiosis. Academic, London.

Smith, S.E., Smith, F.A., Jakobsen, I., 2004. Functional diversity in arbuscular mycorrhizal (AM) symbioses: the contribution of the mycorrhizal P uptake pathway is not correlated with mycorrhizal responses in growth or total P uptake. New Phytol. 162, 511-524.

van der Heijden, E.W., Kuyper, T.W., 2001. Does origin of mycorrhizal fungus or mycorrhizal plant influence effectiveness of the mycorrhizal symbiosis? Plant Soil 230, 161-174.

Wagg, C., Jansa, J., Schmid, B., van der Heijden, M., 2011. Belowground biodiversity effects of plant symbionts support aboveground productivity. Ecol. Lett. 14, 1001-1009.

White, T.J., Bruns, T., Lee, S., Taylor, J., 1990. Amplification and direct sequencing of fungal ribosomal RNA genes for phylogenetics. In: Innis, M.A., Gelfand, D.H., Shinsky, J.J., White, T.J. (Eds.), PCR Protocols. A Guide to Methods and Applications. Academic Press, San Diego, pp. 315-322. 